\title{
PENGARUH GAYA MENGAJAR GURU FIQIH TERHADAP MOTIVASI BELAJAR SISWA MTSN PURWOASRI KAB. KEDIRI
}

\author{
Vinallia \\ Program Studi Pendidikan Agama Islam Pascasajana IAI Tribakti Kediri
}

\begin{abstract}
Abstrak.
Gaya guru mengajar yang jelas dan menarik sangat dibutuhkan dalam prosempembelajaran. Karenanya guru yang kompeten selalu harapkan kehadiarannya dalam sistem pendidikan, khususnya di Indonesia. Tujuan penerapan gaya mengajar salah satunya untuk memberikan pengetahuan ke anak agar ilmu yang disampaikan oleh guru mudah dipelajari dan tujuan dari inti materi dapat terlaksana, serta meningkatkan kualitas pendidikan. Sementara motivasi belajar merupakan aspek yang sangat penting yang dapat mempengaruhi perilaku belajar siswa. Rumusan masalah dalam hal ini: 1) Bagaimana gaya mengajar guru fiqih di MTsN Purwoasri? 2) Bagaimana motivasi belajar fiqih siswa kelas VII di MTsN Purwoasri? 3) Adakah pengaruh yang signifikan antara gaya mengajar guru fiqih terhadap motivasi belajar fiqih siswa kelas VII di MTsN Purwoasri? Penelitian ini bertujuan untuk mengetahui:1) gaya mengajar guru Fiqih di MTsN Purwoasri 2) Motivasi belajar fiqih siswa kelas VII di MTsN Purwoasri 3) Pengaruh gaya mengajar guru Fiqih terhadap motivasi belajar fiqih siswa kelas VII di MTsN Purwoasri. Penelitian ini menggunakan pendekatan kuantitatif dengan jenis penelitian korelasional. Populasi peneitian ini adalah siswa-siswi kelas VII MTsN Purwoasri dengan jumlah 250 siswa dan sampel 152 siswa. Tehnik pengambilan sampel menggunakan Simple Random Sampling. Pengumpulan data dilakukan melalui angket atau kuesioner. Dan analisis datanya menggunakan regresi linear. Hasil penelitian ini adalah gaya mengajar guru Fiqih di MTsN Purwoasri dikategorikan baik, dengan nilai rata-rata sebesar 200,75; sedangkan untuk motivasi belajar siswa di MTsN Purwoasri dikategorikan cukup, dengan nilai ratarata 142,28 . Berdasarkan uji statistik dapat disimpulkan bahwa ada pengaruh antara gaya mengajar guru Fiqih terhadap motivasi belajar siswa di MTsN Purwoasri. Hasil uji F angka koefisien determinasi menunjukkan 0,277. Dengan demikian dapat ditarik kesimpulan bahwa pengaruh gaya mengajar guru Fiqih terhadap motivasi belajar siswa di MTsN Purwoasri sebesar 27,7\% dan sisanya 72, $3 \%$ dipengaruhi oleh faktor-faktor yang lain.
\end{abstract}

\section{Kata Kunci : Gaya Mengajar Guru Fiqih dan Motivasi Belajar Siswa}

\section{Pendahuluan}

Gaya guru mengajar yang jelas dan menarik sangat dibutuhkan dalam prosempembelajaran. Karenanya guru yang kompeten selalu harapkan kehadiarannya dalam sistem pendidikan, khususnya di Indonesia. Tujuan penerapan gaya mengajar salah satunya untuk memberikan pengetahuan ke anak agar ilmu yang disampaikan oleh guru mudah dipelajari dan tujuan dari inti materi dapat terlaksana, serta meningkatkan kualitas pendidikan. Sementara motivasi belajar merupakan aspek yang sangat penting yang dapat mempengaruhi perilaku belajar siswa.

Salah satu kompetensi yang harus dimiliki oleh guru adalah performance (kinerja), yaitu seperangkat perilaku nyata yang ditunjukkan oleh guru yang terkait dengan gaya mengajar, kemampuan berinteraksi dengan siswa, dan karakteristik pribadinya yang ditampilkan pada waktu melaksanakan tugas profesionalnya sebagai pendidik (pembimbing, pengajar 
dan pelatih). ${ }^{1}$ Gaya mengajar merupakan salah satu kompetensi kinerja seorang guru.

Tujuan utama penerapan gaya mengajar tak lain adalah untuk memberikan pengetahuan ke anak agar ilmu yang disampaikan oleh guru mudah dipelajari, serta tujuan dari inti materi bisa terlaksanakan. Dan tujuan umumnya adalah meningkatkan kualitas pendidikan. Terutama apabila gaya pendidikan dibawah tersebut dapat diterapkan dalam pembelajaran kurikulum sekarang yaitu kurikulum 2013. Adapun macam-macam gaya dalam mengajar, yaitu: 1) Gaya mengajar klasik, 2) Gaya mengajar teknologis, 3) Gaya mengajar personalisasi, 4) Gaya mengajar interaksional.

Dalam hal ini gaya mengajar guru memerlukan adanya variasi. Mengadakan variasi merupakan keterampilan yang harus dikuasai guru dalam pembelajaran, untuk mengatasi kebosanan peserta didik, agar selalu antusias, tekun dan penuh partisipasi. Variasi dalam pembelajaran adalah perubahan dalam proses kegiatan untuk meningkatkan motivasi belajar peserta didik, serta mengurangi kejenuhan dan kebosanan. ${ }^{2}$.

Dari beberapa definisi diatas dapat disimpulkan bahwa gaya mengajar guru merupakan hal yang sangat penting dalam proses pembelajaran karena sangat mempengaruhi siswa dalam belajar. Jika guru tidak memiliki gaya mengajar yang baik, maka besar pengaruhnya bagi peserta didik. Dari gaya mengajar tersebut guru dapat menggunakan cara atau metode yang digunakan guru ketika sedang melakukan pengajaran untuk mengatasi siswa agar tidak merasa bosan dalam proses belajar mengajar. Pada dasarnya gaya mengajar yang dimiliki guru adalah strategi yang digunakan untuk mentransfer informasi yang diberikan kepada siswa agar memiliki motivasi belajar.

1 Syamsul Yusuf dan Nani M.S (2013), Perkembangan Peserta Didik, Rajawali, Jakarta, hlm. 139-140.

2 E. Mulyasa (2008), Menjadi Guru Profesional, Remaja Rosdakarya, Bandung, hlm. 78-79.
Motivasi terjadi apabila seseorang mempunyai keinginan dan kemauan untuk melakukan suatu kegiatan atau tindakan dalam rangka mencapai tujuan tertentu. Keinginan dan kemauan pun didasarkan atas sebuah kebutuhan.

Menurut teori Abraham Maslow juga disebutkan "bahwa kebutuhan manusia dapat diklasifikasikan ke dalam lima hirarkhi kebutuhan, yaitu kebutuhan fisiologis, kebutuhan akan keamanan, kebutuhan sosial, kebutuhan "esteem", dan kebutuhan untuk aktualisasi diri" ${ }^{3}$

Oleh sebab itu dalam rangka membangkitkan motivasi, guru harus dapat menunjukkan pentingnya pengalaman dan materi belajar bagi kehidupan siswa, dengan demikian siswa akan belajar bukan hanya sekedar untuk memperoleh nilai atau pujian akan tetapi didorong oleh keinginan untuk memenuhi kebutuhannya. ${ }^{4}$

Pada intinya, motivasi merupakan kondisi psikologis yang mendorong seseorang untuk melakukan sesuatu. Dalam kegiatan belajar, motivasi dapat dikatakan sebagai keseluruhan daya penggerak di dalam diri siswa yang menimbulkan, menjamin kelangsungan, dan memberikan arah kegiatan belajar, sehingga diharapkan tujuan dapat tercapai. Dalam kegiatan belajar, motivasi sangat diperlukan, sebab seseorang yang tidak mempunyai motivasi dalam belajar, tidak akan mungkin melakukan aktivitas belajar dengan baik. ${ }^{5}$

Berlatar belakang dari ketertarikan penulis untuk mengkaji tentang gaya mengajar guru, maka penulis melakukan penelitian lebih mendalam untuk menjabarkan gaya mengajar guru yang sesungguhnya.

Rumusan penelitian ini ada tiga macam yaitu, bagaimanakah gaya mengajar guru Fiqih di MTsN Purwoasri,

3Sondang P. Siagian, Teori Motivasi dan Aplikasinya (2004), Rineka Cipta, Jakarta, hlm.146.

4Wina Sanjaya (2006), Strategi Pembelajaran Berorientasi Standar Proses Pendidikan, Putra Grafika, Jakarta, hlm. 135.

5 Jamal Ma'mur Asmani (2011), 7 Tips Aplikasi PAIKEM, Diva, Yogyakarta, hlm.150-151. 
bagaimanakah motivasi belajar Fiqih siswa kelas VII di MTsN Purwoasri, dan adakah pengaruh yang signifikan antara gaya mengajar guru Fiqih terhadap motivasi belajar fiqih siswa kelas VII di MTsN Purwoasri.

\section{Kajian Teori \\ Kajian tentang Gaya Mengajar Guru}

Dalam merencanakan strategi yang tepat, guru harus mengetahui kemampuan peserta didik dan memilih metode pembelajaran yang akan digunakan sebagai strategi pembelajaran. Pembelajaran menggunakan gaya mengajar yang dikembangkan oleh Mosston (1986). Mosston menggunakan STS (spectrum of teaching style), dimana spektrum tersebut berada di antara serangkaian gaya, dari gaya mengajar berpusat pada guru hingga gaya mengajar berpusat pada peserta didik. $^{6}$

Tujuan utama penerapan gaya mengajar tak lain adalah untuk memberikan pengetahuan ke anak agar ilmu yang disampaikan oleh guru mudah dipelajari, serta tujuan dari inti materi bisa terlaksanakan. Dan tujuan umumnya adalah meningkatkan kualitas pendidikan. Terutama apabila gaya pendidikan dibawah tersebut dapat diterapkan dalam pembelajaran kurikulum sekarang yaitu kurikulum 2013.

Dalam hal ini gaya mengajar guru memerlukan adanya variasi. Mengadakan variasi merupakan keterampilan yang harus dikuasai guru dalam pembelajaran, untuk mengatasi kebosanan peserta didik, agar selalu antusias, tekun dan penuh partisipasi. Variasi dalam pembelajaran adalah perubahan dalam proses kegiatan untuk meningkatkan motivasi belajar peserta didik, serta mengurangi kejenuhan dan kebosanan. ${ }^{7}$.

Variasi dalam proses pembelajaran meliputi tiga aspek, yaitu variasi dalam gaya mengajar, variasi dalam menggunakan media dan bahan

6http://www.gayamengajar.com/2014/08/h tml, diakses tanggal 1 Agustus 2016.

7 E. Mulyasa (2008), Menjadi Guru Profesional, Remaja Rosdakarya, Bandung, hlm. 78-79. pengajaran dan variasi dalam interaksi antara guru dan siswa. Guru tidak boleh asal mengambil dalam menggunakan media, karena dari sekian banyak media belum tentu sesuai dengan karakteristik siswa di kelas. Oleh sebab itu guru harus mengkombinasikan ketiga komponen tersebut dan menyesuaikan dengan karakteristik siswa. Variasi lebih bersifat proses daripada produk. ${ }^{8}$

Gaya mengajar yang bersifat kurikuler adalah guru mengajar yang disesuaikan dengan tujuan dan sifat mata pelajaran tertentu. Sedangkan gaya mengajar yang bersifat psikologis adalah guru mengajar yang disesuaikan dengan motivasi siswa, pengelolaan kelas dan evaluasi hasil belajar. ${ }^{9}$ Makna gaya mengajar diatas, terkait dengan kurikuler, gaya mengajar yaitu gaya mengajar guru menuntut adanya perbedaan tujuan dan sifat antara satu bidang studi dengan bidang studi yang lainnya. Tentunya berbeda gaya mengajar bidang studi agama dengan bidang studi biologi. Sedangkan yang terkait dengan psikologis memungkinkan banyak kesamaan dalam gaya mengajar, karena menyangkut pemberian motivasi pada siswa, cara pengelolaan kelas dan cara mengevaluasi hasil belajar yang sudah mempunyai kesamaan teori secara umum, walaupun terkadang juga menuntut perbedaan yang disebabkan oleh kondisi siswa antara wilayah satu dengan wilayah lainnya.

Komunikasi yang efektif dan efisien dapat diperoleh bila memperhatikan kondisi siswa. Dalam pembelajaran guru harus memiliki keterampilan dalam mengajar salah satunya yaitu variasi gaya mengajar. Apabila guru menggunakan variasi gaya mengajar dengan baik maka akan siswa akan memiliki motivasi yang tinggi dalam belajar sehingga tujuan yang diinginkan akan tercapai. Istilah Al-Quran "fii anfusihiim", artinya penyampaian dengan "bahasa" masyarakat setempat.

8http://www.kompasiana.com/dianmaestro/ variasi-mengajar-dalam-pembelajaran, diakses tanggal 1Agustus 2016.

9 Thoifuri, Menjadi Guru Inisiator (2007), RaSAIL Media Group, Semarang, hlm. 81. 
Artinya dalam menyampaikan pembelajaran harus disesuaikan dengan kondisi siswa, sehingga komunikasi dalam proses pembelajaran dapat diterima siswa manakala guru menyentuh otak atau akal juga hatinya sekaligus.

Proses belajar mengajar dapat berjalan dengan baik dan lancar manakala ada interaksi yang kondusif antara guru dan siswa. Komunikasi yang arif dan bijaksana memberikan kesan mendalam bagi para siswa. Faktor guru ikut menentukan dalam keberhasilan proses kegiatan belajar mengajar, sehingga guru diharuskan untuk memiliki keterampilan dalam mengajar, salah satunya adalah dalam variasi gaya mengajar. Sehingga siswa mampu mengamalkan apa yang disampaikannya tersebut.

Dari gaya mengajar tersebut guru dapat menggunakan cara atau metode yang digunakan guru ketika sedang melakukan pengajaran untuk mengatasi siswa agar tidak merasa bosan dalam proses belajar mengajar. Pada dasarnya gaya mengajar yang dimiliki guru adalah strategi yang digunakan untuk mentransfer informasi yang diberikan kepada siswa agar memiliki motivasi belajar.

\section{Kajian tentang Fiqih}

Fiqih adalah salah satu bidang ilmu dalam syariat Islam yang secara khusus membahas persoalan hukum yang mengatur berbagai aspek kehidupan manusia, baik kehidupan pribadi, bermasyarakat maupun kehidupan manusia dengan Tuhannya. Beberapa ulama fikih seperti Imam Abu Hanifah mendefinisikan fikih sebagai pengetahuan seorang muslim tentang kewajiban dan haknya sebagai hamba Allah. ${ }^{10}$

Dalam fiqih membahas tentang cara bagaimana cara tentang beribadah, tentang prinsip rukun Islam dan hubungan antar manusia sesuai dengan dalil-dalil yang terdapat dalam Al-Qur'an dan Sunnah. Dalam Islam, terdapat 4 mazhab dari Sunni,

10 Abu Hamid Al Ghazali, Al Mushthafa Fi Ilm Al Ushul, Dar Al Kutub Al Ilmiyah, Beirut, hlm. 150.
1 mazhab dari Syiah, dan Khawarij yang mempelajari tentang fikih. Seseorang yang sudah menguasai ilmu fiqih disebut Fakih.

Secara etimologi dalam bahasa Arab, secara harfiah fikih berarti pemahaman yang mendalam terhadap suatu hal. Beberapa ulama memberikan penguraian bahwa arti fikih secara terminologi yaitu fikih merupakan suatu ilmu yang mendalami hukum Islam yang diperoleh melalui dalil di Al-Qur'an dan Sunnah. ${ }^{11}$ Selain itu fikih merupakan ilmu yang juga membahas hukum syar'iyyah dan hubungannya dengan kehidupan manusia sehari-hari, baik itu dalam ibadah maupun dalam muamalah.

Dalam ungkapan lain, sebagaimana dijelaskan dalam sekian banyak literatur, bahwa fiqh adalah "al-ilmu bil-ahkam asysyar'iyyah al-amaliyyah al-muktasab min adillatiha at-tafshiliyyah", ilmu tentang hukum-hukum syari'ah praktis yang digali dari dalil-dalilnya secara terperinci". Terdapat sejumlah pengecualian terkait pendefinisian ini. Dari "asy-syar'iyyah" (bersifat syari'at), dikecualikan ilmu tentang hukum-hukum selain syariat, seperti ilmu tentang hukum alam, seperti gaya gravitasi bumi. Dari "al-amaliyyah" (bersifat praktis, diamalkan), ilmu tentang hukum-hukum syari'at yang bersifat keyakinan atau akidah, ilmu tentang ini dikenal dengan ilmu kalam atau ilmu tauhid. Dari "at-tafshiliyyah" (bersifat terperinci), ilmu tentang hukum-hukum syari'at yang didapat dari dalil-dalilnya yang "ijmali" (global), misalkan tentang bahwasanya kalimat perintah mengandung muatan kewajiban, ilmu tentang ini dikenal dengan ilmu ushul fiqh.

\section{Kajian tentang Motivasi Belajar}

Motivasi dan belajar merupakan dua hal yang saling mempengaruhi. Belajar adalah perubahan tingkah laku secara relatif permanen dan secara potensial terjadi sebagai hasil dari praktik atau penguatan (reinforced practice) yang

11 Rahmat Syafei (1999), Ilmu Ushul Fikih, Pustaka Setia, Bandung, hlm. 18. 
dilandasi tujuan untuk mencapai tujuan tertentu. ${ }^{12}$

Dalam proses belajar, motivasi dapat tumbuh, hilang atau berubah dikarenakan faktor-faktor yang mempengaruhinya. Beberapa faktor-faktor yang mempengaruhi motivasi belajar, yaitu sebagai berikut: Cita-cita atau aspirasi, kemampuan belajar, kondisi siswa, kondisi lingkungan,

\section{Pengaruh Gaya Mengajar Guru Fiqih Terhadap Motivasi Belajar Siswa}

Gaya mengajar guru adalah salah satu faktor yang mempengaruhi tercapainya tujuan pembelajaran dan pendidikan disekolah, namun gaya mengajar tidak berdiri sendiri, tetapi dipengaruhi oleh faktor latar belakang pendidikan, pengalaman mengajar dan lamanya mengajar. Gaya mengajar masuk dalam kompetensi guru yang dapat dinilai penting sebagai alat seleksi dalam penerimaan calon guru, juga dapat dijadikan sebagai pedoman dalam rangka pembinaan dan pengembangan tenaga guru. Selain itu, juga penting dalam hubungannya dengan kegiatan belajar mengajar dan hasil belajar siswa. ${ }^{13}$

Berkaitan dengan kegiatan belajar mengajar, seorang siswa membutuhkan guru yang mampu membimbing dan memberikan dorongan untuk mencapai tujuan belajarnya. Demikian dengan gaya mengajar guru yang mampu mempengaruhi motivasi belajar dan tercapainya tujuan pembelajaran di sekolah.

Motivasi merupakan dorongan dan kekuatan dalam diri seseorang untuk melakukan tujuan tertentu yang ingin dicapainya. Pernyataan ahli tersebut, dapat diartikan bahwa yang dimaksud tujuan adalah sesuatu yang berada di luar diri manusia sehingga kegiatan manusia lebih terarah karena seseorang akan berusaha

12 Ibid., hlm 23

13Agus Wibowo dan Hamrin, Menjadi Guru Berkarakter: Strategi Membangun Kompetensi dan Karakter Guru, hlm.107. lebih semangat dan giat dalam berbuat sesuatu. ${ }^{14}$

Adanya gaya mengajar yang dimiliki guru tidak mungkin proses kegiatan belajar mengajar dapat berlangsung tanpa adanya dorongan diri siswa untuk belajar. Begitu pula dengan motivasi belajar pada siswa, mana mungkin tumbuh tanpa adanya dorongan dari seorang guru yang memiliki gaya mengajar sebagaimana mestinya. Namun bukan berarti gaya mengajar guru merupakan satu-satunya faktor yang mempengaruhi motivasi belajar siswa, sebab masih ada faktor selain gaya mengajar guru yang mempengaruhi, antara lain minat, pendekatan belajar, cita-cita, kemampuan belajar, kondisi siswa, kondisi lingkungan, unsur-unsur dinamis dalam belajar, dan lain-lain. ${ }^{15}$

Tuntutan memiliki variasi mengajar dalam gaya mengajar sebagaimana diuraikan, telah mendorong guru untuk memperoleh informasi yang dapat memperkaya kemampuan agar tidak mengalami ketinggalan. Ketika para guru telah memiliki gaya mengajar, maka secara langsung akan berpengaruh pada proses pengelolaan pendidikan, sehingga mampu melahirkan keluaran (output) pendidikan yang bermutu.

Dari penjelasan di atas dapat disimpulkan bahwa adanya gaya mengajar pada guru sangat berpengaruh terhadap motivasi belajar siswa.

\section{Metode Penelitian}

Pendekatan penelitian ini menggunakan penelitian kuantitatif dengan penekatan field research. Penelitian ini bertujuan menganalisis pengaruh gaya mengajar guru fiqih terhadap motivasi belajar siswa mtsn purwoasri. Penggalain data menggunakan angket. Sedangkan analisis datanya menggunakan teknik analisis $\mathrm{T}$ tes.

\section{Hasil Penelitian}

Berdasarkan data yang diperoleh dari hasil penelitian, pada bab ini akan

\footnotetext{
${ }^{14}$ Ibid., hlm. 8

15Ibid., hlm. 292-293.
} 
dijelaskan mengenai hasil penelitian yang ditinjau secara teoritis dan empiris. Sebagaimana yang telah diuraikan pada rumusan masalah yaitu ingin mengetahui ada tidaknya pengaruh secara signifikan antara gaya mengajar guru fiqih terhadap motivasi belajar siswa di MTsN Purwoasri.

Untuk menjawab permasalahan pada penelitian ini, maka akan dilakukan pengujian data menggunakan analisis regresi linear atau sederhana. Namun sebelumnya akan dijelaskan mengenai hasil analisis dari tingkat gaya mengajar guru fiqih dan motivasi belajar siswa di MTsN Purwoasri. Adapun hasil dari pengolahan data tersebut dijelaskan sebagai berikut :

\section{Gaya mengajar guru fiqih di MTsN Purwoasri}

Nilai rata-rata gaya mengajar guru fiqih di MTsN Purwoasri sebesar 200,75 dan standart deviasinya sebesar 21,509. Setelah dihitung dengan berpedoman pada kategorisasi penilaian gaya mengajar guru fiqih dengan mengambil sampel sebanyak 152 siswa, 9 siswa (6\%) menyatakan gaya mengajar guru fiqih sangat baik, 50 siswa (33\%) gaya mengajar guru fiqih baik, 47 siswa (31\%) gaya mengajar guru fiqih cukup, 33 siswa (22\%) gaya mengajar guru fiqih kurang, 13 siswa (9\%) gaya mengajar guru fiqih sangat kurang.

Dari tabel true score di atas dapat diketahui bahwa tingkat dari gaya mengajar guru fiqih di MTsN Purwoasri dengan nilai rata-rata sebesar 200,75 yang tergolong dalam kategori baik.

Hal ini didukung dengan perolehan informasi dari hasil peninjauan melalui pernyataan yang disampaikan oleh salah satu guru PAI dan beberapa guru lainnya di madrasah tersebut. Dari hasil pernyataannya mengungkapkan bahwa, untuk gaya mengajar guru fiqih-nya sudah baik dalam arti dari karakteristiknya yang dimiliki itu dapat dikatakan sudah mumpuni untuk diaplikasikan pada siswa atau peserta didik, namun memang diakui masih ada satu hal yang memang dapat dikatakan itu merupakan suatu kendala dalam berlangsungnya proses belajar. Dan hal yang menjadi kendalanya yakni penyesuaian metode atau teknik yang tepat dan sesuai untuk kondisi siswa, terutama dalam meningkatkan motivasi belajar pada mereka. Hal ini menjadi harapan (khususnya guru Fiqih) agar kerjasama atau interaksi guru dengan siswa didalam maupun diluar kelas dapat terjalin dengan baik, dengan kata lain proses belajar mengajar yang dilaksanakan seorang guru itu dapat berhasil.

Hal ini didukung dengan pernyataan dari Oemar Hamalik yang menyatakan bahwa proses belajar dan hasil belajar para siswa bukan saja ditentukan oleh madrasah, pola, struktur dan isi kurikulumnya, akan tetapi sebagian besar ditentukan oleh kompetensi guru yang mengajar dan membimbing mereka. Guru yang kompeten akan lebih mampu menciptakan lingkungan belajar yang efektif, menyenangkan dan akan lebih mampu mengelola kelasnya, sehingga belajar para siswa berada pada tingkat optimal. ${ }^{16}$

\section{Motivasi belajar siswa di MTsN Purwoasri}

Nilai rata-rata motivasi belajar siswa MTsN Purwoasri sebesar 142,28 dan standart deviasinya sebesar 14,421. Setelah dihitung dengan berpedoman pada kategorisasi penilaian motivasi belajar siswa dengan mengambil sampel sebanyak 152 siswa, terdapat 10 siswa (7\%) memiliki motivasi belajar sangat tinggi, 38 siswa (25\%) memiliki motivasi belajar tinggi, 59 siswa (39\%) memiliki motivasi belajar cukup, 30 siswa (20\%) memiliki motivasi belajar rendah, 15 siswa $(10 \%)$ memiliki motivasi belajar sangat rendah.

Dari tabel true score diatas dapat diketahui bahwa tingkat motivasi belajar siswa di MTsN Purwoasri dengan nilai rata-rata sebesar 142,28 yang tergolong dalam kategori cukup.

Motivasi dan belajar merupakan dual hal yang saling mempengaruhi. Belajar adalah perubahan tingkah laku secara

160emar Hamalik (2008), Pendidikan Guru Berdasarkan Pendekatan Kompetensi, Bumi Aksara, Jakarta, hln. 36. 
relatif permanen dan secara potensial terjadi sebagai hasil dari praktik atau penguatan (reinforced practice) yang dilandasi tujuan untuk mencapai tujuan tertentu.

Menurut Hamzah B.Uno menyatakan bahwa, motivasi belajar dapat timbul karena faktor intrinsik, berupa hasrat dan keinginan berhasil dan dorongan kebutuhan belajar, harapan akan cita-cita. Sedangkan faktor ekstrinsiknya adalah adanya penghargaan, lingkungan belajar yang kondusif dan kegiatan belajar yang menarik. Tetapi harus diingat, kedua faktor tersebut disebabkan oleh rangsangan tertentu, sehingga seseorang berkeinginan untuk melakukan aktivitas belajar yang lebih giat dan semangat.

Hakikat motivasi belajar adalah dorongan internal dan eksternal pada siswa-siswa yang sedang belajar untuk mengadakan perubahan tingkah laku, pada umumnya dengan beberapa indikator atau unsur yang mendukung. Hal itu mempunyai peranan besar dalam keberhasilan seseorang dalam belajar.

Indikator motivasi belajar dapat diklasifikasikan sebagai berikut: (1) adanya hasrat dan keinginan berhasil, (2) adanya dorongan dan kebutuhan dalam belajar, (3) adanya harapan dan cita-cita masa depan, (4) adanya penghargaan dalam belajar, (5) adanya kegiatan yang menarik dalam belajar, (6) adanya lingkungan belajar yang kondusif, sehingga memungkinkan seseorang siswa dapat belajar dengan baik. ${ }^{17}$

Motivasi adalah usaha-usaha untuk menyediakan kegiatan-kegiatan untuk mencapai tujuan-tujuan tertentu. Walaupun motivasi tumbuh di dalam diri individu (manusia atau siswa), tetapi dalam perkembangannya dapat dirangsang oleh faktor dari luar seperti orang tua, lingkungan, guru dan yang lainnya. ${ }^{18}$

${ }^{17}$ Hamzah B. Uno(2008), Teori Motivasi dan Pengukuranny: Analisis di Bidang Pendidikan, Bumi Aksara, Jakarta, hlm. 23.

18Heri Gunawan (2012), Kurikulum dan Pembelajaran Pendidikan Agama Islam, Alfabeta, Bandung, hlm. 141.
Begitu juga dengan motivasi belajar siswa di sekolah ini, khususnya dalam mata pelajaran fiqih. Dari hasil peninjauan tehadap para siswa (kelas VII) melalui pendekatan yang peneliti lakukan, mayoritas siswa menyatakan bahwa mata pelajaran fiqih kurang menarik meskipun mereka memahami bahwa pelajaran tersebut sangat berarti dan bermanfaat untuk kehidupan kedepannya.

\section{Pengaruh gaya mengajar guru fiqih terhadap motivasi belajar siswa di MTsN Purwoasri}

Dari hasil uji analisis regresi linear dapat diketahui bahwa $F_{\text {hitung }}$ sebesar 57,604 sedangkan untuk $F$ tabel;0,05; $1 ; 150$ dengan $\mathrm{dk} \mathrm{v}_{1}=1$ dan $\mathrm{dk} \mathrm{v}_{2}=150$, Maka $\mathrm{F}_{\text {hitung }}>\mathrm{F}_{\text {tabel }}$ atau dengan tingkat signifikansi sebesar 0,00 yang lebih rendah dari Alpha sebesar 0,05 maka dapat dikatakan bahwa Ho ditolak dan $\mathrm{Ha}$ diterima, sehingga dapat disimpulkan bahwa gaya mengajar guru fiqih secara signifikan mempengaruhi motivasi belajar siswa di MTsN Purwoasri .

Gaya mengajar guru merupakan cara atau metode yang digunakan ketika sedang melakukan pengajaran untuk menyesuaikan dengan karakteristik anak, salah satunya agar tidak merasa bosan dalam proses belajar mengajar. Pada dasarnya gaya mengajar yang dimiliki guru juga strategi yang digunakan untuk mentranfer informasi yang diberikan kepada siswa agar siswa memiliki motivasi belajar.

Untuk gaya mengajar di MTsN Purwoasri menggunakan jenis gaya mengajar klasik, dimana dalam proses pengajaran diupayakan untuk memelihara nilai-nilai lama dari generasi terdahulu ke generasi berikutnya.

Sedangkan motivasi merupakan dorongan dan kekuatan dalam diri seseorang untuk melakukan tujuan tertentu yang ingin dicapainya. Pernyataan ahli tersebut, dapat diartikan bahwa yang dimaksud tujuan adalah sesuatu yang berada di luar diri manusia sehingga kegiatan manusia lebih terarah karena 
seseorang akan berusaha lebih semangat dan giat dalam berbuat sesuatu. ${ }^{19}$

Untuk memenuhi kebutuhan belajar siswa dalam gaya mengajar yang dimilikinya, seorang guru juga membentuk peserta didiknya agar memiliki dorongan untuk memiliki rasa ingin tahu terhadap apa yang disampaikan guru terhadap siswanya. Secara tidak langsung jadi gaya mengajar yang dibawakan oleh guru akan mendorong siswa untuk melakukan sesuatu hal yang berkaitan dengan tujuan belajar itu sendiri.

Namun dilihat bahwa koefisien determinasi gaya mengajar guru fiqih terhadap motivasi belajar siswa adalah sebesar 0,277. Jadi dapat dikatakan bahwa gaya mengajar guru fiqih mempengaruhi motivasi belajar siswa sebesar $27,7 \%$ dan sisanya $72,3 \%$ dipengaruhi oleh faktor lain. Artinya faktor-faktor di luar gaya mengajar guru lebih dominan dalam mempengaruhi motivasi belajar siswa. Adapun faktor lain yang mempengaruhinya dapat berupa minat, pendekatan belajar, cita-cita, kemampuan belajar, kondisi siswa, kondisi lingkungan, unsur-unsur dinamis dalam belajar, dan lain-lain. ${ }^{20}$

Menurut Thomas L. Good dan Jere E. Bophi mengatakan bahwa, " motivasi juga dipengaruhi oleh keadaan emosi seseorang. Guru dapat memberikan motivasi siswa dengan melihat suasana emosional siswa tersebut. Menurutnya baik motivasi belajar maupun berprestasi dimiliki oleh setiap orang, sedangkan intensitasnya tergantung pada kondisi mental orang tersebut."21

Tuntutan memiliki gaya mengajar untuk seorang guru, telah mendorong guru untuk memperoleh informasi yang dapat memperkaya kemampuan agar tidak mengalami ketinggalan. Ketika para guru telah memiliki gaya mengajar, maka secara langsung akan berpengaruh pada proses pengelolaan pendidikan, sehingga mampu

19Ibid., 8.

20U. Saefullah (2012), Psikologi Perkembangan dan Pendidikan, Pustaka Setia, Bandung, hlm. 292-293.

${ }^{21}$ Ibid. melahirkan keluaran (output) pendidikan yang bermutu.

\section{Kesimpulan}

Berdasarkan penjelasan dari hasil diatas maka dapat diambil kesimpulan bahwa pengaruh gaya mengajar guru fiqih terhadap motivasi belajar siswa, sebagai berikut:

Gaya mengajar guru fiqih di MTsN Purwoasri dikategorikan baik, dengan nilai rata-rata sebesar 200,75. Artinya tingkat gaya mengajar guru fiqih memiliki skor tertinggi yakni 240 dan terendah 134 dengan selisih 106 yang dibagi dengan 5 acuan katerogi dengan skor 21,2. Dan adapun jenis gaya mengajar yang digunakan yakni gaya mengajar klasik.

Motivasi belajar siswa di MTsN Purwoasri dikategorikan cukup, dengan nilai rata-rata 142,28. Artinya bahwa tingkat motivasi belajar siswa dengan skor tertinggi 172 dan terendah 102, dengan selisih 70 dan dibagi 5 acuan kategori dengan skor 14.

Ada, dan untuk pengaruh gaya mengajar guru fiqih terhadap motivasi belajar siswa di MTsN Purwoasri, sesuai angka koefisien determinasi gaya mengajar guru fiqih mempengaruhi motivasi belajar siswa adalah sebesar 0,277. Dapat dikatakan bahwa gaya mengajar guru fiqih mempengaruhi motivasi belajar siswa sebesar $\quad 27,7 \%$ dan sisanya $72,3 \%$ dipengaruhi oleh faktor lain.

\section{Daftar Pustaka}

Ahmadi. Lif Khoiru, dkk. (2011) Pembelajaran Akselerasi: Analisis Teori Dan Praktik Serta Pengaruhnya Terhadap Mekanisme Pembelajaran Dalam Kelas Akselerasi, Prestasi Pustaka, Jakarta.

Al Ghazali, Abu Hamid. (1999) Al Mushthafa Fi Ilm Al Ushul, Dar Al Kutub Al Ilmiyah, Beirut.

Al Masudy, Hasan. (2000) Taysir Khollaq, Maktabah Ibnu Ahmad, Surabaya.

Al Qayyim, Ibnu I,Lam Al Muwaqqiin, Dar Al Khutub Al Hadists, Kairo. 
Anwar, Ali. (2009) Statistika Untuk Penelitian Pendidikan Dan Aplikasinya Dengan SPSS Dan Excel, IAIT Press, Kediri.

Arikunto, Suharsimi. (2002) Prosedur Penelitian: Suatu Pendekatan Praktek, Rineka Cipta, Yogyakarta.

Asmani, Jamal Ma'mur. (2011) 7 Tips Aplikasi Paikem, Diva, Yogyakarta.

Creswell, John W. (2009) Research Design: Pendekatan Kualitatif, Kuantitatif Dan Mixed, terj. Ahmad fawaid, pustaka pelajar, Yogyakarta.

Djamarah, Syaiful Bahri. (2005) Guru Dan Anak Didik Dalam Interaksi Edukatif, Rineka Cipta, Jakarta.

Fudyartanto, Ki RBS. (2002) Psikologi Pendidikan, Global Pustaka Utami, Yogyakarta.

Goble, Frank G. (1987) Madzab Ketiga Psikologi Humanistik Abraham Maslow, Kanisias, Yogyakarta.

Gunawan, Heri. (2012) Kurikulum Dan Pembelajaran Pendidikan Agama Islam, Alfabeta, Bandung.

Hamalik, Oemar. (2008) Pendidikan Guru Berdasarkan Pendekatan Kompetensi, Bumi Aksara, Jakarta.

Hasan, Chalidjah. (1994) Dimensi-Dimensi Psikologi Pendidikan, Al-Ikhlas, Surabaya.

Hasanah, Aan. (2012) Pengembangan Profesi Guru, Pustaka, Bandung.

Hasibuan, J.J. dan Moedjiono. (2010) Proses Belajar Mengajar, Remaja Rosdakarya, Bandung.

Hawi, Akmal. (2013) Kompetensi Guru Pendidikan Agama Islam, Raja Grafindo Persada, Jakarta.

Idris, Marno dan M. (2010) Strategi \& Metode Pengajaran, Ar Ruzz Media, Jogjakarta.
Idrus, Muhammad. (2007) Metode IlmuIlmu Sosial: Pendekatan Kualitatif Dan Kuantitatif, UII Pres, Yogyakarta.

Indrakusuma, Amir Daien. (1973) Pengantar Ilmu Pengetahuan, Usaha Nasional, Surabaya.

Latipah, Eva. (2012) Pengantar Psikologi Pendidikan, Pustaka Insan Madani, Yogyakarta.

Madkur, Muhammad Salam. (1976) Manahij Al Ijtihad Fi Al Islam , University Kuwait, Kuwait.

Mahmud. (2011) Metode Penelitian Pendidikan, Pustaka Setia, Bandung.

Mudlofir, Ali. (2013) Pendidikan Profesional, Raja Grafindo Persada, Jakarta.

Mulyasa, E. (2008) Mengajar Guru Profesional, Remaja Rosdakarya, Bandung.

Murni, Wahid. (2010) Keterampilan Dasar Mengajar, Ar-Ruzz Media, Jogjakarta.

Nurcholis, Ahmad dan Jusuf Bahtiar. (Juni 2012) Strategi Pengembangan Kreativitas Dan Motivasi Belajar Siswa, Ta'alum (Jurnal Pendidikan Islam), No. 1, Vol. 22.

Pullians, Earl V. And James D. Young. (1968) A Teacher Is Many Things, Indiana University Press, USA.

Purwanto, Ngalim. (1998) Psikologi Pendidikan, Remaja Rosdakarya, Bandung.

Riduwan. (2010) Skala Pengukuran Variabel-Variabel Penelitian, Alfabeta, Bandung.

Saefullah, U. (2012) Psikologi Perkembangan Dan Pendidikan, Pustaka Setia, Bandung.

Sanjaya, Wina. (2006) Strategi Pembelajaran Berorientasi Standar 
Jumal Pendidikan dan Studi Keislaman

Proses Pendidikan, Putra Grafika, Jakarta.

Siagian, Sondang P. (2004) Teori Motivasi Dan Aplikasinya, Rineka Cipta, Jakarta.

Sugiono. (2008) Statistika Untuk Penelitian, Alfabeta, Bandung.

Sugiyono. (2008) Metode Penelitian Kuantitatif, Kualitatif Dan $R \& D$, Alfabeta, Bandung.

Suryobroto, B. (2009) Proses Belajar Mengajar Di Sekolah, Rineka Cipta, Jakarta.

Syafei, Rahmat. (1999) Ilmu Ushul Fiqih, Pustaka Setia, Bandung.

Syah, Muhibbin. (2008) Psikologi Belajar, Raja Grafindo Persada, Jakarta.

Tadjab. (1994) Ilmu Jiwa Dan Pendidikan, Karya Abditama, Surabaya.

Thoifuri. (2007) Menjadi Guru Inisiator, Rasail Media Group, Semarang.

Uno, Hamzah. (2008) Teori Motivasi Dan Pengukurannya, Bumi Aksara, Jakarta.

Usman, Moch.Uzer. (2011) Menjadi Guru Profesional, Remaja Rosdakarya, Bandung.

Wibowo, Agus dan Hamrin.(2012) Menjadi Guru Berkarakter; Strategi Membangun Kompetensi Dan Karakter Guru, Pustaka Pelajar, Yogyakarta.

Yusuf, Syamsul dan Nani M.S. (2013) Perkembangan Peserta Didik, Rajawali, Jakarta. 